\title{
Equity Incentive and Growth of Executives in Mixed Ownership Enterprises Listed Manufacturing Enterprises Based on State-Owned Holdings
}

\author{
Xinhong Wang, Huan Liang \\ School of Management, Xi'an University of Science and Technology, Xi'an, China \\ Email: 13679118144@163.com
}

How to cite this paper: Wang, X.H. and Liang, H. (2019) Equity Incentive and Growth of Executives in Mixed Ownership Enterprises Listed Manufacturing Enterprises Based on State-Owned Holdings. Open Access Library Journal, 6: e5039.

https://doi.org/10.4236/oalib.1105309

Received: March 5, 2019

Accepted: March 16, 2019

Published: March 19, 2019

Copyright () 2019 by author(s) and Open Access Library Inc.

This work is licensed under the Creative Commons Attribution International License (CC BY 4.0).

http://creativecommons.org/licenses/by/4.0/

(c) (i) Open Access

\begin{abstract}
This paper takes the state-owned manufacturing mixed-ownership enterprises as the research sample, selects the data from 2014-2016, and studies the relationship between executive equity incentives and corporate growth. Firstly, theoretical analysis is carried out according to the existing literature, and then empirical research is carried out by regression analysis on the basis of theoretical analysis. The research shows that: in the state-owned manufacturing industry, in mixed ownership enterprises, there is a positive correlation between executive equity incentives and corporate growth, but this correlation will be affected by equity concentration. Only when the ratio of the largest shareholder is in the range of $20 \%-50 \%$, the positive correlation between executive equity incentives and corporate growth is significant. The executive equity incentive policy has not significantly promoted the growth of the company in the enterprises with scattered equity or excessive concentration of equity. Based on this, it is proposed that enterprises should establish a reasonable executive equity incentive policy and further optimize the shareholding structure through the reform of state-owned enterprise mixed ownership.
\end{abstract}

\section{Subject Areas}

Financial Reporting, General Business Research, General Management, Management Organization, Managerial Economics

\section{Keywords}

Equity Incentives, Corporate Growth, Mixed Ownership 


\section{Introduction}

With the separation of ownership and management of modern enterprises, the application of principal-agent problem has emerged, and has gradually become one of the urgent problems hindering the growth of enterprises. The research on equity incentive system in western countries is relatively perfect and mature. Compared with the western countries, the equity incentive system in our country started late. The basic formation of the equity incentive policy system from 2006 to 2008 marks the beginning of the real equity incentive practice in our country. The Third Plenary Session of the $18^{\text {th }}$ Central Committee of the Communist Party of China (the decision of the Central Committee of the Communist Party of China on comprehensively deepening the reform of some major issues) proposed to further deepen the reform, and at the same time clarified the direction of mixed ownership reform, and the reform of mixed ownership became a state-owned enterprise to optimize resource allocation, improve governance structure, and seek long-term Favorable measures for development. With the continuous advancement of the mixed ownership reform, on July 13, 2016, the CSRC improved the equity incentive policy and re-issued the Measures for the Administration of Equity Incentives of Listed Companies.

In order to further realize economic transformation through reform, manufacturing industry, as the foundation of national economic and social development, has become the pioneer and focus of China's current mixed ownership reform. How to promote the upgrading of manufacturing industry through mixed ownership reform has become a topic of concern for many scholars. The continuous advancement of mixed ownership reform and the introduction and improvement of relevant policies have led more manufacturing listed companies to choose to implement executive equity incentive policies. Research on executive equity incentives and the future growth potential of enterprises has also been applied, but currently Chinese scholars still have no agreement on the relationship between executive equity incentives and corporate growth. Is the executive equity incentive policy effective under all circumstances? Will executive equity incentives affect the growth of the company? This is not only a topic that the academic community urgently needs to break through, but also an urgent problem to be solved in the practice of mixed ownership reform. Based on this, this paper takes the state-owned manufacturing mixed-ownership enterprises as the object, studies the influence of executive equity incentives on the growth of enterprises, and provides an empirical basis for adjusting and perfecting the equity incentive policies of mixed ownership enterprises in China.

\section{Literature Review}

Regarding the relationship between executive equity incentives and corporate growth, there is still no consensus at home and abroad. The uncoordinated results are due to differences in research perspectives and research methods of different scholars. 


\subsection{The Executive Equity Incentive Is Positively Related to the Growth of the Company}

Most scholars believe that the implementation of executive equity incentives can promote business growth. Marianna et al. (2006) [1] applied the multiple regression method. The study found that once the number of stock options held by senior managers increased, the performance of the company increased, thus improving the future development ability of the company. According to Kaplan (1989) [2], corporate growth will increase with the implementation of management equity incentives. Some scholars in China have analyzed the relationship between executive equity incentives and corporate growth from the perspective of intermediary variables. Wu Yunduan (2015) [3], Hu Yan (2015) [4], Li Zhankui (2017) [5] used the innovation ability of enterprises as a mediator variable, and found that executive equity incentives are promoting the growth of enterprises. Wang Xiufen and Xu Xiaopeng (2017) [6] use business risk as a mediator variable, and through empirical research, it is found that executive equity incentives can promote the improvement of business performance, thereby enhancing the growth of the company, reflecting the executive equity incentives and corporate growth. There is a positive correlation between sex. Some scholars have used case analysis to study the growth of an enterprise before and after the implementation of the executive equity incentive policy. Zhang Wei (2017) [7] takes ZTE as an example, using entropy method to study the relationship between executives' equity incentives and growth, and finds that a reasonable executive equity incentive plan is adopted for China's communications manufacturing listed companies. The growth of corporate growth can play a certain role. In addition to case studies and the introduction of mediator variables, domestic scholars mostly use the method of establishing regression models to study the relationship between executive equity incentives and corporate growth. In the process of establishing regression models, domestic scholars have certain differences in the selection of corporate growth metrics. Li Wei'an (2013) [8] selected total return on assets and return on net assets as a measure of growth, and studied the impact of executive reduction and shareholding structure on the growth of GEM listed companies. Monitoring the behavior and optimizing the ownership structure can improve the company's future development capabilities. Li Yijuan (2016) [9] studied the relationship between executive stock ownership and corporate growth from the perspective of management, and used Tobin $\mathrm{Q}$ to reflect the growth of the company. The study found that executives can promote the growth of the company.

\subsection{Executives' Equity Incentives Are Negatively Correlated with Corporate Growth}

Foreign conclusions about the negative correlation between executive equity incentives and corporate growth originated from Fama and Jensen (1983) [10] objections to traditional agency theory. Traditional agency theory believes that 
agency fees can be reduced through a series of incentives for managers, but Fama and Jensen believe that management personnel are the actual masters of decision-making power in major matters, even if management personnel have a large shareholding, they will not make decisions that restrict its own interests. Instead, it may use the voting rights and influences generated by equity incentives to further satisfy its own interests and neglect the development goals of the enterprise, so that the company's business development capability is reduced, and the growth of the enterprise is limited. Fama and Jensen's views prompted more scholars to jump out of the limitations of traditional agency theory, from the perspective of managerial defense, to study the relationship between executive equity incentives and corporate growth. According to Loderer and Martin (1997) [11], executives' negative holdings affect corporate performance. The conclusions of Wang Qiuxia and Chen Xiaoyi (2007) [12] show that the negative proportion of professional managers' shareholdings affects the operating efficiency of enterprises, but the negative correlation between them is not significant. Zhu Zhilong and Ding Liquan (2003) [13] found through empirical research that executive equity incentives are negatively correlated with corporate growth. Li Xiaojuan (2017) [14] found through empirical research that the implementation of executive equity incentives in state-owned listed companies has a negative impact on the company's performance. The decline in performance will lead to the decline of corporate growth, reflecting the executives' equity incentives. The decline in performance will lead to a decline in corporate growth, which reflects the negative impact of executive equity incentives on corporate growth.

\subsection{Non-Linear Relationship between Executive Equity Incentives and Corporate Growth}

Based on the research of Fama and Jensen, Stulz (1988) [15] officially formalized the management defense hypothesis, and believed that the management shareholding ratio is nonlinearly related to the growth of the firm, but an inverted $\mathrm{U}$-shaped relationship. Stulz proposed that when the proportion of equity incentives to management is low, it can effectively achieve the purpose of equity incentives, improve the enthusiasm of management, and thus promote the growth of enterprises. However, as the proportion of equity incentives rises, when managers have a certain degree of power, managers are more inclined to choose to use these powers to maximize their own interests, and therefore ignore the future development of the company. Therefore, equity incentives are related to the growth curve of the firm. When the incentive ratio is low, the two are negatively correlated. After the incentive ratio reaches a certain level, the two are positively correlated. With the continuous development and improvement of the management defense hypothesis, Chinese scholars have also begun to explore whether there is a nonlinear relationship between equity incentives and corporate growth. Li Wei'an and Li Hanjun (2006) [16] studied the relationship between equity incentives and corporate performance, and found that equity concentration has a greater impact on the implementation of equity incentives. In 
the case of relatively concentrated equity, the relationship between equity incentives and firm performance is inverted U-shaped. Wu Meijun (2012) [17] obtained a non-linear correlation between equity incentives and earnings per share. The incentive effect is most obvious when the incentive ratio is between $3 \%$ and $6 \%$.

\subsection{Equity Incentives for Executives Are Not Related to Corporate Growth}

Although most scholars believe that corporate growth is affected to some extent by executive equity incentives, there are still a few scholars who have proposed that executive equity incentives will not affect the growth of firms. Demsetz and Lehn (1985) [18] used ROE to measure firm growth and found that management shareholdings did not have a significant impact on firm growth. Yu Honglin (2006) [19] used the value of Tobin $Q$ to reflect the value of enterprises from the perspective of different property rights. It was found that in non-state-owned listed companies, there is no direct relationship between the value of enterprises and the proportion of executive equity incentives.

Through the review of related literatures at home and abroad, it is found that corporate governance issues have become the focus of more and more scholars. Whether executive equity incentives will affect the growth of enterprises has become an important topic for scholars at home and abroad, but the current issues on this issue are still different in the conclusions of the study. This paper explores the relationship between state-owned manufacturing-owned mixed-ownership executives' equity incentives and corporate growth, and proposes relevant recommendations for mixed ownership reform based on empirical results.

\section{Theoretical Basis and Research Hypothesis}

In the 1970s, scholars Michael Jensen and William McLean proposed the principal-agent theory, and the study of the principal-agent relationship began. The generation of principal-agent relationship is inseparable from the rapid development of social economy. The implementation of the principal-agent relationship mainly has two problems: First, the conflict of interest between the two parties. The client hopes that the agent can aim at maximizing the interests of shareholders and the value of the company. Agents are more interested in short-term interests such as personal salary, on-the-job consumption, and work environment. In order to meet their short-term needs, agents may ignore the long-term perspective of the company. In order to meet their own short-term needs, agents may ignore the long-term value and future development of enterprises. Second, the information on both sides of the transaction is asymmetric. Due to the asymmetry of information, "reverse selection" and "moral hazard" may occur between the principal and the agent, which may adversely affect the enterprise. The effective incentive of the principal to the agent becomes an effective way to resolve the conflict of interest and information asymmetry between the principal and the agent. The role of executives is critical in the development of the enterprise. According to the provisions of the Company Law of China, se- 
nior management personnel refer to the company's manager, deputy manager, financial controller, board secretary of the listed company and other personnel as stipulated in the company's articles of association. The ability and enthusiasm of executives will determine whether companies can leverage their strengths and optimize resource allocation to promote growth. Therefore, increasing the incentives for executives' equity incentives can solve the problem of principal-agents to a certain extent, so that the goals of shareholders and executives tend to be consistent, so that executives can create value for the company and promote the growth of the company. Based on this, this paper proposes the following assumptions:

Hypothesis 1: Executive equity incentives are significantly positively correlated with corporate growth.

The effectiveness of equity incentives depends on the incentives themselves and on the other hand on the ownership structure of the firm. When the shareholding ratio of the largest shareholder is too low and the equity is too dispersed, it is more conducive to the executives to control the enterprise. In this case, the executives are more inclined to abandon the meager gains brought by the equity incentives and use their own high Participation will seek benefits through other means. At this time, the implementation of executive equity incentive policies will not have a significant impact on the growth of the company. When the first major shareholder has a moderate shareholding ratio, the majority shareholder is more motivated to supervise the executives. Under this circumstance, the positive incentive effect of the executive equity incentive will be more obvious. At this time, equity incentives and corporate growth relationship between sex will also be closer. When the first major shareholder is under absolute control, the executives lack the right to speak in the business process. Even if the equity incentives are made, the executives cannot truly participate in the internal decision-making of the enterprise. Therefore, in this case, the executives are equity. Incentives do not affect the behavior of executives. At this time, the implementation of equity incentives will not have obvious effects, so it will hardly affect the future development of the company. Based on this, this paper proposes the following assumptions:

Hypothesis 2: The status of the first major shareholder's control will affect the relationship between the shareholding ratio of executives and the growth of the company.

\section{Research Design}

\subsection{Sample Selection and Data Source}

Manufacturing industry accounts for a large proportion of China's national production and development. With the advancement of the reform process, the state pays more and more attention to the development of manufacturing industry. Therefore, this paper will study the relationship between equity incentive and enterprise growth in manufacturing mixed ownership enterprises under the background of manufacturing mixed ownership reform. Based on the 2012 edition of China Securities Regulatory Commission Industry Classification, this 
paper selects the state-owned manufacturing mixed-ownership enterprise from 2014 to 2016 as a sample. On this basis, in order to ensure the accuracy of the research, the selected samples are screened as follows: 1) Listed companies with S, ST, and ${ }^{*}$ ST; 2) Excluding sample companies with missing major data; 3) Excluding sample companies with outliers for each major variable. After the above treatment, a total of 799 research samples were obtained.

The data used in this paper are all from Guotai'an database, and the data is processed by SPSS 21.0 software.

\subsection{Variable Design}

1) Interpreted variable

This paper studies the relationship between executive equity incentives and corporate growth, and selects corporate growth as an explanatory variable. In the existing research, the indicators used to measure the growth of the enterprise mainly include two types of indicators: single indicator and comprehensive index. This paper selects a single indicator to measure the growth of the enterprise. Performance indicators such as earnings per share and return on net assets commonly used in domestic literature are greatly affected by accounting data. In order to fully reflect the real situation of listed companies, this paper adopts the Tobin Q value which can comprehensively consider the market value factor of listed companies as a measure of growth.

2) Explanatory variables

This paper selects the shareholding ratio of executives as an explanatory variable. Because executive equity incentives are currently the most important and the most widely implemented equity incentives, the shareholding ratio of executives can intuitively reflect the intensity of executive equity incentives.

3) Control variables

In order to more accurately study the relationship between executive equity incentives and corporate growth, this paper selects some other variables related to corporate growth as control variables, including equity balance, firm size, asset-liability ratio and free cash flow. The meaning of the variables is shown in Table 1.

Table 1. variable description

\begin{tabular}{|c|c|c|c|}
\hline Variable nature & Variable name & Symbol & Calculation formula \\
\hline Explained variable & TobinQ value & Q & Market value/total assets \\
\hline \multirow[t]{5}{*}{ Explanatory variables } & Executive shareholding ratio & MSR & Total number of shares held by senior management/total number of shares \\
\hline & Equity balance & $\mathrm{S}$ & $\begin{array}{l}\text { The sum of the shareholding ratio of the company's second } \\
\text { largest shareholder to the tenth largest shareholder }\end{array}$ \\
\hline & Business scale & SIZE & Natural logarithm of total assets \\
\hline & Assetsand liabilities & LEV & Total liabilities/total assets \\
\hline & Freecash flow & FCFF & $\begin{array}{l}\text { (net profit }+ \text { interest expense }+ \text { non-cash expenditure) } \\
\text { - working capital addition - capital expenditure }\end{array}$ \\
\hline
\end{tabular}




\section{4) Model design}

Based on the logical reasoning of relevant theories, this paper establishes a multiple linear regression model, analyzes the relationship between equity incentives and firm growth, and establishes the following model ( $v$ is the error term):

$$
Q=\beta+\beta_{1} \mathrm{MSR}+\beta_{2} S+\beta_{3} \mathrm{SIZE}+\beta_{4} \mathrm{LEV}+\beta_{5} \mathrm{FCFF}+U
$$

\section{Empirical Analysis}

\subsection{Descriptive Statistical Analysis}

In order to further understand the overall situation of each variable and lay the foundation for regression analysis, this paper will perform descriptive statistical analysis on each variable, as shown in Table 2.

It can be seen from Table 2 that the sample company has a maximum $Q$ value of 28.6358 and a minimum of 0.1285 , indicating that there is a large gap in the growth of China's state-owned manufacturing mixed-ownership enterprises. The maximum shareholding ratio of executives is 0.6161 , and the minimum value is close to 0 . Because the proportion of samples close to 0 is large, the average shareholding ratio of executives is only 0.0088 . It shows that in the mixed ownership enterprises of state-owned holding manufacturing industry, the incentive of executive equity is generally low and the proportion of executive equity incentives varies greatly depending on the specific conditions of each company. The maximum value of the $S$ index is 59.8225, and the minimum value is 0.7066. From the huge difference between the maximum value and the minimum value, it can be seen that the equity balance of the state-owned manufacturing mixed-ownership enterprises in China is too high or too low. The maximum size of the enterprise is 27.1045 , and the minimum value is 19.0773 . The gap in enterprise size is relatively small. The average asset-liability ratio is 0.5019 , which indicates that the state-owned mixed-management manufacturing enterprises in China have better financial status and the enterprises have certain solvency. The maximum and minimum values of free cash flow are very different. Generally speaking, enterprises with good business performance have more free cash flow. Therefore, it can be seen that there is a big gap in the operating performance of China's state-controlled manufacturing mixed-ownership enterprises.

Table 2. Variable descriptive statistical analysis table.

\begin{tabular}{ccccc}
\hline variable & $\min$ & $\max$ & average value & standard deviation \\
\hline $\mathrm{Q}$ & 0.1285 & 28.6358 & 1.9658 & 2.0248 \\
MSR & 0.0000 & 0.6161 & 0.0088 & 0.03961 \\
$\mathrm{~S}$ & 0.7066 & 59.8225 & 18.6789 & 11.8051 \\
SIZE & 19.0773 & 27.1045 & 22.7293 & 1.3455 \\
LEV & 0.0156 & 1.3448 & 0.5019 & 0.2110 \\
FCFF & $-6,158,437$ & $931,910,727$ & $1,016,230,765$ & 641,031 \\
\hline
\end{tabular}




\subsection{Correlation Analysis and Multicollinearity Test}

The emergence of multicollinearity makes the variable significance test of the regression model meaningless, which makes it difficult to accurately estimate or estimate the distortion of the regression model. In order to avoid the regression model failure, this paper will analyze the correlation and multicollinearity of each variable before the regression analysis. Inspection, see Table 3.

It can be seen from Table 3 that each explanatory variable has a good correlation with the interpreted variable and can be used to describe the interpreted variable. It can be seen from the variance expansion factor of each explanatory variable that the variance expansion factor between all explanatory variables is less than 2. It is generally considered that when the variance expansion factor exceeds 10 , it indicates that there is collinearity between the variables, so it is also possible to judge each variable. There is no multicollinearity between them. Further regression analysis can be performed.

\subsection{Multiple Regression Analysis}

1) Overall regression analysis

This paper uses SPSS21.0 statistical software for regression analysis to study the relationship between executive equity incentives and corporate growth. The regression analysis was performed according to the model constructed above, and the specific results are shown in Table 4 and Table 5.

From Table 4, we can see that the adjusted R-side of the model is 0.391 , which shows that the model fits well and can effectively express the relationship between equity incentives and enterprise growth.

It can be seen from Table 5 that in the state-owned manufacturing mixedownership enterprises, the equity incentives of the executives are positively related to the growth of the enterprises, and the $1 \%$ significance test level is passed. The equity incentives can stimulate the work motivation of the executives, thus affecting the enterprises. The future development potential and the growth of the

Table 3. Correlation analysis and multicollinearity test.

\begin{tabular}{cccccccc}
\hline variable & Q & MRS & S & SIZE & LEV & FCFF & VIF \\
\hline Q & 1 & & & & & & \\
MRS & $0.191^{* *}$ & 1 & & & & 1.084 \\
S & 0.026 & $0.207^{* *}$ & 1 & & & 1.125 \\
SIZE & $-0.584^{* *}$ & $-0.115^{* *}$ & $0.137^{* *}$ & 1 & & & 1.379 \\
LEV & $-0.403^{* *}$ & $-0.180^{* *}$ & $-0.102^{* *}$ & $0.399^{* *}$ & 1 & & 1.245 \\
FCFF & $-0.104^{* *}$ & -0.022 & $-0.095^{* *}$ & $0.296^{* *}$ & $0.089^{*}$ & 1 & 1.125 \\
\hline
\end{tabular}

Table 4. Model summary.

\begin{tabular}{cccccc}
\hline model & $\mathrm{R}$ & $\mathrm{R}^{2}$ & Adjusted R side & Standard estimated error & Durbin-Watson \\
\hline 1 & $0.628^{\mathrm{a}}$ & 0.395 & 0.391 & 1.580292905 & 1.836 \\
\hline
\end{tabular}


company. That is to say, with the increase of executive equity incentive, the principal-agent problem in enterprises will be alleviated to a certain extent, the interests of managers and the development goals of enterprises will gradually converge, more willing to contribute to the development of enterprises, thus promoting the growth of enterprises, thus, hypothesis 1 is verified.

2) Group regression analysis

In order to further analyze the relationship between equity concentration, executive shareholding ratio and corporate growth in state-owned manufacturing mixed-ownership enterprises, this paper conducts a group regression analysis based on the shareholding ratio of the largest shareholder. The two major demarcation points of $20 \%$ and $50 \%$ as the shareholding ratio of the largest shareholder are divided into three groups: a) CRI $<20 \%$, at which time the shareholding is relatively scattered, and the control ability of the first largest shareholder is weak: b) $20 \% \leq \mathrm{CRI}<50 \%$, at this time the first major shareholder is in a relatively controlling position, which has a significant impact on corporate governance decisions: c) $50 \% \leq \mathrm{CRI} \leq 100 \%$, at this time the first major shareholder is in absolute control status. Using the above model to perform multiple linear regression analysis on the three sets of sample data, the following results were obtained.

It can be seen from Table 6 that the shareholding ratio of the first largest shareholder of state-owned manufacturing mixed-ownership enterprises is mainly concentrated between $20 \%$ and $50 \%$, accounting for $73 \%$ of the total sample. It can be seen that the current state-owned holdings manufacturing mixed-ownership enterprises as a whole are in a state of relatively dispersed equity. When the shareholding ratio of the largest shareholder is greater than $50 \%$, the shareholding structure of the enterprise is excessively concentrated. In this

Table 5. Overall regression analysis results.

\begin{tabular}{|c|c|c|c|c|c|}
\hline \multirow{2}{*}{ model } & \multicolumn{2}{|c|}{ Non-standardized coefficient } & \multirow{2}{*}{$\begin{array}{l}\text { Standard } \\
\text { coefficient }\end{array}$} & \multirow{2}{*}{$\mathrm{t}$} & \multirow{2}{*}{ Sig. } \\
\hline & B & Standard error & & & \\
\hline (constant) & 20.961 & 1.041 & & 20.131 & 0.000 \\
\hline Executive shareholding ratio & 4.306 & 1.470 & 0.084 & 2.928 & 0.004 \\
\hline$S$ index & 0.012 & 0.005 & 0.073 & 2.483 & 0.013 \\
\hline Business scale & -0.812 & 0.049 & -0.540 & -16.631 & 0.000 \\
\hline Assets and liabilities & -1.659 & 0.296 & -0.173 & -5.608 & 0.000 \\
\hline Free cash flow & $2.557 \mathrm{E}-011$ & 0.000 & 0.081 & 2.751 & 0.006 \\
\hline
\end{tabular}

Table 6. Descriptive statistics of the shareholding ratio of executives after grouping.

\begin{tabular}{cccccc}
\hline & N & Min & Max & Mean & Standard deviation \\
\hline $\mathrm{CRI}<20 \%$ & 93 & 0.00001 & 0.23355 & 0.01421 & 0.03946 \\
$20 \% \leq \mathrm{CRI}<50 \%$ & 583 & 0.00000 & 0.61611 & 0.00961 & 0.04339 \\
$50 \% \leq \mathrm{CRI} \leq 100 \%$ & 123 & 0.00000 & 0.04098 & 0.00090 & 0.00404 \\
\hline
\end{tabular}


range, the maximum shareholding ratio of the executives is only 0.04098 . Therefore, it can be seen that the shareholding ratio of the largest shareholder is Enterprises within this range pay less attention to equity incentives.

After the group regression (Table 7), it can be found that when the shareholding ratio of the first largest shareholder is less than $20 \%$ and the equity is relatively dispersed, there is no significant correlation between the shareholding ratio of the executives and the growth of the enterprise, because the executives control the enterprise at this time. To a higher degree, executives are more inclined to obtain more benefits through other means than equity incentives. When the shareholding ratio of the first largest shareholder is greater than $20 \%$ and less than $50 \%$, the shareholding ratio of the executives is significantly positively correlated with the growth of the enterprise. At this time, the implementation of the equity incentive policy can effectively improve the growth of the enterprise. When the shareholding ratio of the largest shareholder is in this range, there is a certain balance between the major shareholders. At this time, the decision-making ability of the executives is crucial for the development of the enterprise, and the executive equity incentive policy will also play a larger role. When the shareholding ratio of the first largest shareholder exceeds $50 \%$, there will be a phenomenon of "one big share". Executives have no control and discourse power. Even if they exercise equity incentives for executives, executives hold shares held by equity incentives. Compared with the shares held by the major shareholders with actual control rights, it is also insignificant. Therefore, it does not make much sense to implement executive equity incentives at this time.

\section{Conclusions and Recommendations}

\subsection{Conclusion}

After an empirical analysis of the data of China's state-controlled manufacturing mixed-ownership enterprises from 2014 to 2016 for three consecutive years, the following conclusions are drawn: Generally speaking, the equity incentives of senior executives in state-owned manufacturing mixed-ownership enterprises are positively related to the growth of enterprises, and increasing the incentives

Table 7. Model regression coefficient results after grouping.

\begin{tabular}{|c|c|c|c|c|c|c|}
\hline \multirow{2}{*}{ variable } & \multicolumn{2}{|c|}{$\mathrm{CRI}<20 \%$} & \multicolumn{2}{|c|}{$20 \% \leq \mathrm{CRI}<50 \%$} & \multicolumn{2}{|c|}{$50 \% \leq \mathrm{CRI} \leq 100 \%$} \\
\hline & coefficient & $\mathrm{t}$ & coefficient & $\mathrm{t}$ & coefficient & $\mathrm{t}$ \\
\hline MSR & -0.015 & $(0.163)$ & $0.108^{\star * \star}$ & $(3.491)$ & -0.043 & $(0.730)$ \\
\hline$S$ & -0.056 & $(0.596)$ & $0.112^{* * *}$ & $(3.444)$ & $0.165^{\star * *}$ & $(2.672)$ \\
\hline SIZE & $-0.596^{\star * *}$ & $(6.313)$ & $-0.541^{\star * *}$ & $(15.035)$ & $-0.522^{\star * *}$ & $(6.237)$ \\
\hline LEV & $0.238^{\star *}$ & $(2.581)$ & $-0.265^{\star * *}$ & $(7.770)$ & $-0.412^{\star * *}$ & $(5.768)$ \\
\hline FCFF & -0.110 & $(1.197)$ & $0.056^{*}$ & $(1.831)$ & 0.093 & $(1.354)$ \\
\hline Adjusted R side & \multicolumn{2}{|c|}{0.302} & \multicolumn{2}{|c|}{0.491} & \multicolumn{2}{|c|}{0.590} \\
\hline $\mathrm{F}$ & \multicolumn{2}{|c|}{8.977} & \multicolumn{2}{|c|}{113.459} & \multicolumn{2}{|c|}{36.150} \\
\hline
\end{tabular}


for equity of executives will improve the growth of enterprises to a certain extent. From the results of the group analysis, it can be seen that only when the first major shareholder's shareholding ratio is within the range of $20 \%-50 \%$, the correlation between executive equity incentives and corporate growth is significant, indicating that executive equity incentives are not in any enterprise, it can promote the future growth of the company. Enterprises with relatively scattered equity use the executive equity incentive policy to improve growth, and enterprises with scattered or excessive concentration must seek policies other than equity incentives to improve business growth.

\subsection{Suggestions}

First, establish and improve the equity incentive policy for executives. It can be seen from the analysis in the previous article that China's state-owned manufacturing mixed-ownership enterprises currently have fewer incentives for executive equity incentives, which affects the future development potential of enterprises. Growth represents the future development potential of the company. In order to further enhance the development capability of the mixed-ownership enterprise and promote the continuous promotion and deepening of the mixed ownership reform, the enterprise should improve the equity incentive policy, gradually increase the management's equity incentive ratio, and continuously optimize the management's incentive structure.

Second, further optimize the shareholding structure through the reform of state-owned enterprise mixed ownership. The effective play of equity incentives on growth promotion depends to a certain extent on the control position of the largest shareholder. Excessive concentration or excessively dispersed ownership structure will hinder the effect of equity incentives. From the empirical research results, only when a large shareholder's shareholding ratio is in the range of $20 \%$ to $50 \%$, equity incentives will play a greater positive incentive role. The main purpose of the reform of the mixed ownership system lies in the optimization of the shareholding structure. Therefore, in the process of the current state-owned enterprise mixed ownership reform, the enterprise should seize the opportunity of development, accelerate the improvement of the internal governance structure, moderately adjust the concentration of ownership, and effectively exert the supervision of the enterprise. The management mechanism provides favorable conditions for the promotion of equity incentives to promote growth.

\subsection{Deficiencies and Prospects}

This paper studies the relationship between equity incentive and growth of state-owned manufacturing enterprises, and puts forward policy recommendations based on empirical results, but there are still some shortcomings. Limited to manufacturing listed companies, it can not fully represent the development of mixed ownership enterprises. Considering only state-owned holding enterprises, the possible differences between non-state-owned enterprises are ignored. In the 
future research, we should check the omissions and make up for the deficiencies in order to make the article more perfect.

\section{Conflicts of Interest}

The authors declare no conflicts of interest regarding the publication of this paper.

\section{References}

[1] Makri, M., Lane, P.J. and Gomez-Mejia, L.R. (2006) CEO Incentives, Innovation and Performance in Technology-Intensive Firms: A Reconciliation Outcome and Behavior-Based Incentive Schemes. Strategic Management Journal, 27, 1057-1080. https://doi.org/10.1002/smj.560

[2] Steven, K. (1989) The Effects of Management Buyouts on Operating Performance and Value. Journal of Financial Economics, 24, 217-254. https://doi.org/10.1016/0304-405X(89)90047-0

[3] Wu, Y.D. (2015) Executives' Holding, R\&D Investment and Enterprise Performance-Evidence from GEM High-Tech Enterprises. Accounting Newsletter, No. 33, 41-44.

[4] Hu, Y., Hou, W. and Yu, X.R. (2015) Executive Incentives, Innovation Input and Growth. Finance and Accounting Monthly, No. 36, 35-39.

[5] Li, Z.K. (2017) Executive Incentives and Firm Performance-Based on the Mediating Effect of R\&D Investment. Finance and Accounting News, No. 35, 31-36.

[6] Wang, X.F. and Xu, X.P. (2017) Equity Incentives, Business Risks and Firm Performance of Executives. Friends of Accounting, No. 10, 84-89.

[7] Zhang, W. (2017) Research on the Relationship between Equity Incentives and Corporate Growth. Beijing Jiaotong University, Beijing.

[8] Li, W.A., Li, H.C. and Hao, C. (2013) Research on the Influence Mechanism of Executives' Reduction and Corporate Governance Growth of GEM Companies. Management Science, No. 26, 1-12.

[9] Li, Y., Luo, Z.Y. and Zhu, X.C. (2016) Management Power, Executive Shareholding and Corporate Growth. Hubei Social Sciences, No. 9, 106-113.

[10] Fama, E.F. and Michael, C. (1983) Agency Problems and Residual Claims. Journal of Law and Economics, 26, 327-349. https://doi.org/10.1086/467038

[11] Loderer, C. and Martin, K. (1997) Executive Stock Ownership and Performance Tracking Faint Traces. Journal of Financial Economics, 45, 223-255. https://doi.org/10.1016/S0304-405X(97)00017-2

[12] Wang, Q.X. and Chen, X.Y. (2007) An Empirical Study on the Economic Performance of China's Listed Companies after Implementing Equity Incentives. Market Forum, No. 8, 56-58.

[13] Zhu, Z.L. and Ding, L.Q. (2003) An Empirical Study on the Correlation between Incentives and Corporate Performance and Scale. Seeking, No. 5, 18-20.

[14] Li, X.J. (2017) An Empirical Study on the Impact of Equity Incentive Strength on the Performance of Listed Companies. Journal of Social Science of Hunan Normal University, No. 46, 126-132.

[15] Stulz, R.M. (1988) Managerial Control of Voting Rights: Financing Polices and the Market for Corporate Control. Journal of Financial Economics, 20, 25-54. 
https://doi.org/10.1016/0304-405X(88)90039-6

[16] Li, W.A. and Li, H.J. (2006) Equity Structure, Executive Shareholding and Corporate Performance: Evidence from Private Listed Companies. Nankai Management Review, No. 5, 4-10.

[17] Wu, M.J. (2012) Research on the Correlation between Executive Compensation and Corporate Performance of Listed Companies in Financial Industry. New Accounting, No. 1, 15-16.

[18] Desetz, H. and Lehn, K. (1985) The Structure of Corporate Ownership: Causes and Consequences. Journal of Political Economy, 93, 1155-1177. https://doi.org/10.1086/261354

[19] Yu, H.L. (2006) An Empirical Test of the Equity Incentive Effect of Managers in State-Owned Listed Companies. Economic Sciences, No. 1, 108-116. 